\title{
Aplikasi Asuhan Keperawatan Jiwa Pada Ny. T Dengan Masalah Halusinasi
}

\author{
Tri Epipanias Gea
}

epinanias@gmail.com

\section{BAB I \\ PENDAHULUAN}

\subsection{Latar Belakang}

Gangguan jiwa merupakan masalah klinis dan sosial yang harus segera diatasi karena merupakan salah satu bentuk penyimpangan prilaku. Gangguan atau masalah kesehatan jiwa yang berupa proses pikir maupun gangguan persepsi sensori yang sering terjadi adalah halusinasi. Halusinasi merupakan gangguan persepsi sensori tanpa adanya rangsangan apapun pada panca indra seseorang yang terjadi pada keadaan sadar (Erliyani, E. 2019). Masalah gangguan jiwa semakin meningkat, ini dipengaruhi oleh pola perilaku atau psikologis yang ditunjukkan oleh individu yang menyebabkan distress, disfungsi, dan menurunkan kualitas kehidupan. Hal ini mencerminkan disfungsi psikobiologis dan bukan sebagai akibat dari penyimpangan sosial atau konflik dengan masyarakat (Stuart, Keliat \& Pasaribu, 2016).

Skizofrenia merupakan gangguan psikiatri yang menimbulkan disabilitas yang cukup luas, serta dicirikan oleh suatu siklus kekambuhan dan remisi. Sampai saat ini para ahli belum mendapatkan kesepakatan tentang definisi baku dari kekambuhan skizofrenia. Insiden kambuh pasien skizofrenia sangat tinggi, yaitu berkisar 60\%-75\% setelah suatu episode psikotik jika tidak diterapi. Pasien skizofrenia yang tidak teratur minum obat 
mengalami kekambuhan sebesar $74 \%$, di antaranya memerlukan rehospitalisasi sebasar 71\%. (Mubin \& Livana 2019). Skizofrenia menimbulkan distorsi pikiran, distorsi persepsi emosi, dan tingkah laku sehingga pasien dengan skizofrenia memiliki risiko lebih tinggi berperilaku agresif di mana perubahan perilaku secara dramatis terjadi dalam beberapa hari atau minggu. Hal inilah yang membuat perlu bantuan keluarga untuk merawat dan memberikan perhatian khusus pada pasien skizofrenia (Pardede \& Siregar, 2016). Skizofrenia merupakan gangguan mental berat dan kronis yang menyerang 20 juta orang di seluruh dunia (WHO, 2019). Di Indonesia berdasarkan hasil Riskesdas (2018) didapatkan estimasi prevalensi orang yang pernah menderita skizofrenia di Indonesia sebesar 1,8 per 1000 penduduk. Hasil survey awal yang dilakukan di poliklinik rawat jalan Rumah Sakit Jiwa Medan di temukan sebanyak 13.899 pasien yang rawat jalan dibawa oleh keluarganya untuk berobat. Prevalensi pasien berdasarkan jenis kelamin yaitu wanita berjumlah 4.499 orang dan laki - laki berjumlah 9.400 orang. Dari semua diagnosa pasien yang rawat jalan yang paling tinggi yaitu gangguan Skizofrenia yaitu sebesar 11.336 orang dari pasien yang berkunjung dibawa oleh keluarganya ke poli rawat jalan berjumlah 1158 pasien perbulan (Pardede, 2020). Fenomena gangguan jiwa pada saat ini mengalami peningkatan yang sangat signifikan, dan setiap tahun di berbagai belahan dunia jumlah penderita gangguan jiwa bertambah. Menurut WHO (World Health Organization), tahun 2019 masalah gangguan kesehatan jiwa di seluruh dunia sudah menjadi masalah yang serius. WHO memperkirakan sekitar 450 juta orang di dunia yang mengalami gangguan kesehatan jiwa, 135 juta orang diantaranya mengalami halusinasi (Widadyasih, 2019)

Halusinasi merupakan keadaan seseorang mengalami perubahan dalam pola dan jumlah stimulasi yang diprakarsai secara internal atau eksternal disekitar dengan pengurangan, berlebihan, distorsi, atau kelainan berespon terhadap setiap stimulus (Pardede, Keliat \& Wardani 2013). Halusinasi 
adalah suatu gejala pada individu dengan gangguan jiwa yang mengalami gangguan perubahan persepsi sensori yang ditandai dengan klien merasakan sensasi berupa suara, penglihatan, pengecapan, perabaan, atau penghiduan tanpa stimulus yang nyata (Keliat, 2014). Halusinasi pendengaran paling sering terjadi ketika klien mendengar suara-suara, suara tersebut dianggap terpisah dari pikiran klien sendiri. Isi suara-suara tersebut mengancam dan menghina, sering kali suara tersebut memerintah klien untuk melakukan tindakan yang akan melukai klien atau orang lain (Nyumirah, 2013).

Klien dengan halusinasi yang telah dikendalikan oleh halusinasinya akan melakukan perilaku yang membahayakan dirinya, orang lain, dan juga lingkungan (Aldam, 2019). Penanganan secara tepat untuk mengatasi dampak dari halusinasi yakni dengan melakukan Tindakan asuhan keperawatan dan terapi stimulasi. Asuhan keperawatan yang diberikan pada penderita halusinasi bertujuan untuk meningkatkan kesadaran pasien dalam kehidupan nyata. Terapi stimulasi persepsi dalam mengontrol halusinasi yaitu menghardik dengan menutup telinga, mengontrol halusinasi dengan patuh minum obat, mengajak klien untuk mengobrol dengan orang lain, mengajak klien untuk melakukan aktivitas yang paling disukai (Stuart, 2016). Survey awal yang di lakukan di Yayasan Pemenang Jiwa Sumatra dengan jumlah pasien 70 orang tetapi yang menjadi subjek di dalam pembuatan askep ini berjumlah 1 orang dengan pasien masah halusinasi pendengaran atas nama inisial $\mathrm{Ny}$. $\mathrm{T}$, penyebabnya $\mathrm{Ny}$. $\mathrm{T}$ sebagai subjek di karenakan pasien belum bisa mengatasi emosinya selain minum obat. Maka tujuan asuhan keperawatan yang akan di lakukan ialah untuk mengajarkan standar pelaksanaan masalah halusinasi pendengaran pada saat Ny. T mengalami halusinasinya. 


\subsection{Rumusan Masalah}

" Bagaimana memberikan asuhan keperawatan pasa Ny. T dengan masalah halusinasi pendengaran di Yayasan Pemenang Jiwa Sumatera”

\subsection{Tujuan}

\subsubsection{Tujuan Umum}

Mahasiswa mampu memberikan asuhan keperawatan secara holistik dan komprehensif kepada Ny. T dengan gangguan persepsi sensori: halusinasi pendengaran.

\subsubsection{Tujuan Khusus}

1. Mahasiswa mampu melakukan pengkajian pada $\mathrm{Ny}$. $\mathrm{T}$ dengan gangguan persepsi sensori : halusinasi pendengaran.

2. Mahasiswa mampu menegakkan diagnosa keperawatan yang ada pada Ny. T dengan gangguan persepsi sensori : halusinasi pendengaran.

3. Mahasiswa menetapkan perencanaan keperawatan pada $\mathrm{Ny}$. T dengan gangguan persepsi sensori : halusinasi pendengaran.

4. Mahasiswa melakukan implementasi keperawatan pada $\mathrm{Ny}$. T dengan gangguan persepsi sensori : halusinasi pendengaran.

5. Mahasiswa mengevaluasi hasil asuhan keperawatan pada $\mathrm{Ny}$. T dengan gangguan persepsi sensori : halusinasi pendengaran.

6. Mendokumentasikan asuhan keperawatan yang diberikan pada Ny. T dengan gangguan persepsi sensori : halusinasi pendengaran.

\subsection{Manfaat}

\subsubsection{Bagi Klien}

Mendapatkan pengalaman serta dapat menerapkan apa yang telah dipelajari dalam penanganan kasus jiwa yang dialami dengan kasus nyata dalam pelaksanaan keperawatan, seperti cara untuk mengendalikan halusinasinya 


\subsubsection{Bagi Perawat}

Asuhan keperawatan ini dapat dijadikan dasar informasi dan pertimbangan untuk menambah pengetahuan, keterampilan dan sikap dalam meningkatkan pelayanan perawatan pada Klien Gangguan Persepsi Sensori (Halusinasi Pendengaran)

\subsubsection{Bagi Peneliti selanjutnya.}

Asuhan keperawatan ini dapat dijadikan dasar informasi dan pertimbangan peneliti selanjutnya untuk menambah pengetahuan tentang asuhan keperawatan gangguan persepsi sensori: halusinasi pendengaran 


\section{BAB 2 \\ TINJAUAN TEORITIS}

\subsection{Konsep Dasar Halusinasi Pendengaran}

\subsubsection{Pengertian}

Halusinasi merupakan suatu penyerapan panca indera tanpa ada rangsangan dari luar, orang sehat persepsinya akurat,mampu mengidentifikasi dan menginter prestasikan stimulus berdasarkan informasi yang diterimanya melalui panca indera (Aritonang, 2021). Halusinasi adalah salah satu gejala gangguan sensori persepsi yang dialami oleh pasien gangguan jiwa, klien merasakan sensasi berupa suara, penglihatan, pengecapan, perabaan, atau penghiduan tanpa stimulus nyata. (Keliat, 2014). Halusinasi pendengaran paling sering terjadi ketika klien mendengar suara-suara, Suara tersebut dianggap terpisah dari pikiran klien sendiri. Isi suara-suara tersebut mengancam dan menghina, sering kali suara tersebut memerintah klien untuk melakukan tindakan yang akan melukai klien atau orang lain (Nyumirah, 2013). Dari pendapat di atas dapat disimpulkan bahwa halusinasi pendengaran adalah persepsi atau tanggapan dari pancaidera (Mendengar) terhadap stimulus yang tidak nyata yang mempengaruhi perilaku individu.

\subsubsection{Klasifikasi Halusinasi}

Menurut Yusuf (2015) klasifikasi halusinasi dibagi menjadi 5 yaitu :

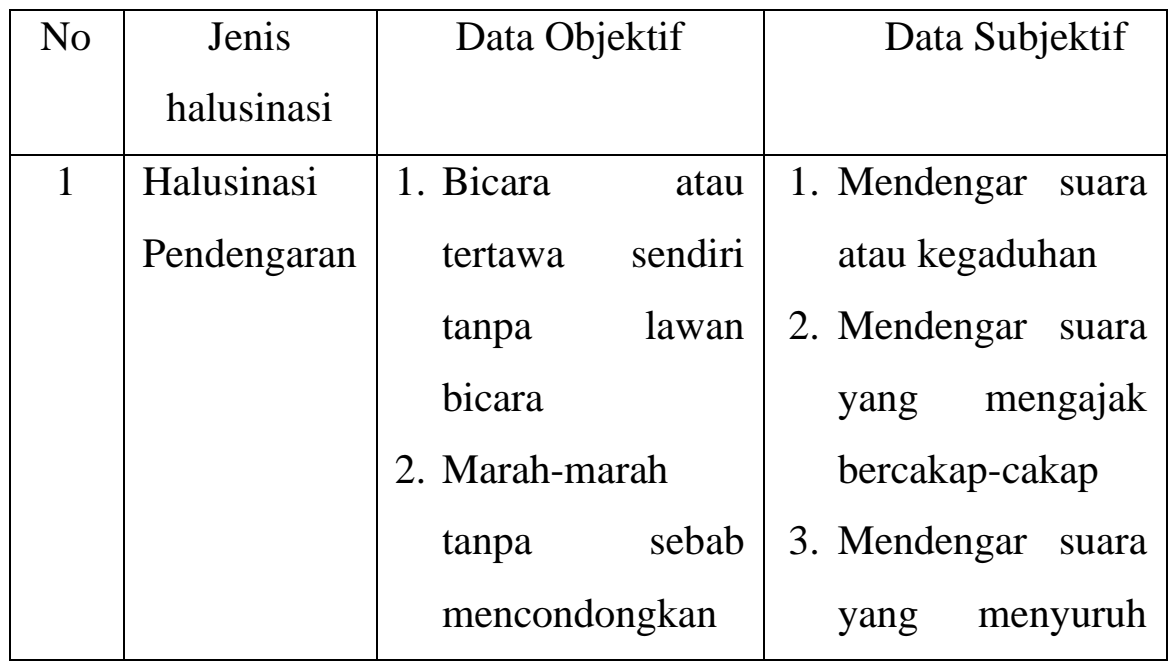




\begin{tabular}{|c|c|c|c|}
\hline & & $\begin{array}{l}\text { telinga ke arah } \\
\text { tertentu } \\
\text { 3. Menutup telinga }\end{array}$ & $\begin{array}{l}\text { melakukan } \\
\text { sesuatu yang } \\
\text { berbahaya }\end{array}$ \\
\hline 2 & $\begin{array}{l}\text { Halusinasi } \\
\text { penglihatan }\end{array}$ & $\begin{array}{l}\text { 1. Menunjuk-nunjuk } \\
\text { ke arah tertentu } \\
\text { 2. Ketakutan pada } \\
\text { objek yang tidak } \\
\text { jelas }\end{array}$ & $\begin{array}{l}\text { 1. Melihat bayangan, } \\
\text { sinar, bentuk } \\
\text { geometris, bentuk } \\
\text { kartun, melihat } \\
\text { hantur atau } \\
\text { monster }\end{array}$ \\
\hline 3 & $\begin{array}{l}\text { Halusinasi } \\
\text { penghindu }\end{array}$ & $\begin{array}{l}\text { 1. Menghindu } \\
\text { seperti sedang } \\
\text { membaui bau- } \\
\text { bauan tertentu } \\
\text { 2. Menutup hidung }\end{array}$ & $\begin{array}{l}\text { 1. Membaui bau- } \\
\text { bauan seperti bau } \\
\text { darah, urine, feses, } \\
\text { 2. kadang-kadang } \\
\text { bau itu } \\
\text { menyenangkan }\end{array}$ \\
\hline 4 & $\begin{array}{l}\text { Halusinasi } \\
\text { pengecepan }\end{array}$ & $\begin{array}{l}\text { 1. Sering meludah } \\
\text { 2. Muntah }\end{array}$ & $\begin{array}{l}\text { 1. Merasakan rasa } \\
\text { seperti darah, } \\
\text { urine, feses }\end{array}$ \\
\hline 5 & $\begin{array}{l}\text { Halusinasi } \\
\text { perabaan }\end{array}$ & $\begin{array}{l}\text { Menggaruk-garuk } \\
\text { permukaan kulit }\end{array}$ & $\begin{array}{l}\text { 1. Mengatakan ada } \\
\text { serangga di } \\
\text { permukaan kulit } \\
\text { 2. Merasa seperti } \\
\text { tersengat listrik }\end{array}$ \\
\hline
\end{tabular}

\subsubsection{Etiologi}

\section{Faktor Predisposisi}

Faktor predisposisi sebagai faktor risiko yang menjadi sumber terjadinya stres yang mempengaruhi tipe dan sumber dari individu untuk menghadapi stres baik yang biologis, psikososial dan sosial kultural. Membedakan stressor predisposisi menjadi tiga, meliputi biologis, psikologis dan sosial budaya. Stressor predisposisi ini kejadiannya telah berlalu (Stuart, 2013). 
Penjelasan secara rinci tentang ketiga stressor predisposisi tersebut sebagai berikut menurut Keliat (2014) :

\section{a. Biologis}

Faktor biologis terkait dengan adanya neuropatologi dan ketidakseimbangan dari neurotransmiternya. Dampak yang dapat dinilai sebagai manifestasi adanya gangguan adalah perilaku maladaptif klien . Secara biologi riset neurobiologikal memfokuskan pada tiga area otak yang dipercaya dapat melibatkan klien mengalami halusinasi yaitu sistem limbik, lobus frontalis dan hypothalamus.

Pada klien dengan halusinasi diperkirakan mengalami kerusakan pada sistem limbic dan lobus frontal yang berperan dalam pengendalian atau pengontrolan perilaku, kerusakan pada hipotalamus yang berperan dalam pengaturan mood dan motivasi. Kondisi kerusakan ini mengakibatkan klien halusinasi tidak memiliki keinginan dan motivasi untuk berperilaku secara adaptif. Klien halusinasi juga diperkirakan mengalami perubahan pada fungsi neurotransmitter, perubahan dopamin, serotonin, norepineprin dan asetilkolin yang menyebabkan adanya perubahan regulasi gerak dan koordinasi, emosi, kemampuan memecahkan masalah; perilaku cenderung negatif atau berperilaku maladaptif; terjadi kelemahan serta penurunan atensi dan mood.

Genetik juga dapa memicu terjadi halusinasi pada seorang individu.Faktor genetik dapat berperan dalam respon sosial maladaptif. Terjadinya penyakit jiwa pada individu juga dipengaruhi oleh keluarganya dibanding dengan individu yang tidak mempunyai penyakit terkait. Banyak riset menunjukkan peningkatan risiko mengalami skizofrenia pada individu dengan riwayat genetik terdapat anggota keluarga dengan 
skizofrenia. Pada kembar dizigot risiko terjadi skizofrenia $15 \%$, kembar monozigot $50 \%$, anak dengan salah satu orang tua menderita skizofrenia berisiko $13 \%$, dan jika kedua orang tua mendererita skizofrenia berisiko $45 \%$.

\section{b. Psikologis}

Meliputi konsep diri, intelektualitas, kepribadian, moralitas, pengalaman masa lalu, koping dan keterampilan komunikasi secara verbal . Konsep diri dimulai dari gambaran diri secara keseluruhan yang diterima secara positif atau negatif oleh seseorang. Penerimaan gambaran diri yang negative menyebabkan perubahan persepsi seseorang dalam memandang aspek positif lain yang dimiliki.

Peran merupakan bagian terpenting dari konsep diri secara utuh. Peran yang terlalu banyak dapat menjadi beban bagi kehidupan seseorang, hal ini akan berpengaruh terhadap kerancuan dari peran dirinya dan dapat menimbulkan depresi yang berat. Ideal diri adalah harapan, cita-cita serta tujuan yang ingin diwujudkan atau dicapai dalam hidup secara realistis. Identitas diri terkait dengan kemampuan seseorang dalam mengenal siapa dirinya, dengan segala keunikannya. Harga diri merupakan kemampuan seseorang untuk menghargai diri sendiri serta member penghargaan terhadap kemampuan orang lain.

Klien yang mengalami halusinasi memandang dirinya secara negatif sering mengabaikan gambaran dirinya, tidak memperhatikan kebutuhannya dengan baik. Intelektualitas ditentukan oleh tingkat pendidikan seseorang, pengalaman dan interaksi dengan lingkungan ketika mengalami halusinasi. Kepribadian pada klien halusinasi biasanya ditemukan klien memiliki kepribadian yang tertutup. Klien tidak mudah 
menerima masukan dan informasi yang berkaitan dengan kehidupan klien. Klien juga jarang bergaul dan cenderung menutup diri. Klien memiliki ketidakmampuan untuk mengevaluasi atau menilai keadaan dirinya dan tidak mampu memutuskan melakukan peningkatan keadaan menjadi lebih baik.

Moralitas pandangan negatif terhadap diri sendiri ini menyebabkan klien mengalami penurunan motivasi untk melakukan aktifitas. Kesimpulannya, adanya penilaian diri yang negatif pada diri klien dengan halusinasi menyebabkan tidak ada tanggung jawab secara moral pada klien untuk melakukan aktifitas.

Menurut beberapa penjelasan di atas dapat diambil suatu kesimpulan bahwa jika mempunyai pengalaman masa lalu yang tidak menyenangkan, klien mempunyai konsep diri negatif, intelektualitas yang rendah, kepribadian dan moralitas yang tidak adekuat merupakan penyebab secara psikologis untuk terjadinya halusinasi. Klien halusinasi memerlukan perhatian yang cukup besar untuk dapat mengembalikan konsep diri yang seutuhnya yang menyebabkan klien suka menyendiri, melamun dan akhirnya muncul halusinasi.

c. Sosial Budaya

Meliputi status sosial, umur, pendidikan, agama, dan kondisi politik. Menurut Nyumirah, (2013) ada beberapa hal yang dikaitkan dengan masalah gangguan jiwa. Salah satunya yang terjadi pada klien halusinasi adalah masalah pekerjaan yang akan mempengaruhi status sosial. Klien dengan status sosial ekonomi yang rendah berpeluang lebih besar untuk mengalami gangguan jiwa dibandingkan dengan klien yang memiliki status sosial ekonomi tinggi. 
Faktor sosial ekonomi tersebut meliputi kemiskinan, tidak memadainya sarana dan prasarana, tidak adekuatnya pemenuhan nutrisi, rendahnya pemenuhan kebutuhan perawatan untuk anggota keluarga, dan perasaan tidak berdaya. Kultur atau budaya, kepercayaan kebudayaan klien dan nilai pribadi mempengaruhi masalah klien dengan halusinasi. Berdasarkan beberapa pernyataan tersebut dapat disimpulkan bahwa status social ekonomi, pendidikan yang rendah, kurangnya pengetahuan, motivasi yang kurang dan kondisi fisik yang lemah dapat mempengaruhi klien dalam mempertahankan aktifitas klien yang mengalami halusinasi.

\section{Faktor Presipitasi}

Secara umum klien dengan gangguan halusinasi timbul gangguan setelah adanya hubungan yang bermusuhan, tekanan, isolasi, perasaan tidak berguna, putus asa dan tidak berdaya. Penilaian individu terhadap stressor dan masalah koping dapat mengindikasikan kemungkinan kekambuhan (Keliat, 2014). Faktor presipitasi sebagai suatu stimulus yang dipersepsikan oleh individu apakah dipersepsikan sebagai suatu kesempatan, tantangan, ancaman/tuntutan.

Stressor presipitasi bisa berupa stimulus internal maupun eksternal yang mengancam individu. Komponen stressor presipitasi terdiri atas sifat, asal, waktu dan jumlah stressor (Stuart, 2013). Sifat stresor, terjadinya halusinasi berdasarkan sifat terdiri dari :

a. Komponen biologis, misalnya penyakit infeksi, penyakit kronis atau kelainan struktur otak, ketidakteraturan dalam proses pengobatan.

b. Komponen psikologis, misalnya: intelegensi, ketrampilan verbal, moral, kepribadian dan kontrol diri, pengalaman yang tidak menyenangkan, kurangnya motivasi. 
c. Komponen sosial budaya, misalnya: adanya aturan yang sering bertentangan antara individu dan kelompok masyarakat, tuntutan masyarakat yang tidak sesuai dengan kemampuan seseorang, ataupun adanya stigma dari masyarakat terhadap seseorang yang mengalami gangguan jiwa, sehingga klien melakukan perilaku yang terkadang menentang hal tersebut yang menurut masyarakat tidak sesuai dengan kebiasaan dan lingkungan setempat.

Asal stresor terdiri dari internal dan eksternal. Stresor internal atau yang berasal dari diri sendiri seperti persepsi individu yang tidak baik tentang dirinya, orang lain dan lingkungannya, merasa tidak mampu, ketidakberdayaan. Stresor eksternal atau berasal dari luar diri seperti kurangnya dukungan keluarga, dukungan masyarakat, dukungan kelompok/teman sebaya, dan lain-lain. Waktu dilihat sebagai dimensi kapan stresor mulai terjadi dan berapa lama terpapar stressor sehingga menyebabkan munculnya gejala. Lama dan jumlah stresor yaitu terkait dengan sejak kapan, sudah berapa lama, berapa kali kejadiannya (frekuensi) serta jumlah stresor (Stuart, 2013).

Saat pertama kali terkena masalah, maka penanganannya juga memerlukan suatu upaya yang lebih intensif dengan tujuan untuk pencegahan primer. Frekuensi dan jumlah stresor juga mempengaruhi individu, bila frekuensi dan jumlah stresor lebih sedikit juga akan memerlukan penanganan yang berbeda dibandingkan dengan yang mempunyai frekuensi dan jumlah stresor lebih banyak. Berbagai penyebab/stressor di atas, yang meliputi stressor predisposisi dan stressor presipitasi yang dialami oleh klien halusinasi akan memunculkan beberapa respon. Respon tersebut merupakan pikiran, sikap, tanggapan, 
perasaan dan perilaku yang ditunjukkan pada klien halusinasi terhadap kejadian yang dialami.

\subsubsection{Rentang Respon Neurobiologi}

Rentang respon neurobiologi (Stuart 2013) :

\begin{tabular}{|c|c|c|}
\hline Adaptif & Mal ad & ptif \\
\hline $\begin{array}{l}\text { Pikiran logis } \\
\text { Persepsi akurat } \\
\text { Emosi konsisten } \\
\text { dengan pengalaman } \\
\text { Perilaku sesuai } \\
\text { Hubungan social } \\
\text { positif }\end{array}$ & $\begin{array}{l}\text { Kadang pikiran } \\
\text { terganggu } \\
\text { Ilusi } \\
\text { Emosi } \\
\text { berlebihan/kurang } \\
\text { Perilaku yang tidak bisa } \\
\text { Menarik diri }\end{array}$ & $\begin{array}{l}\text { Gangguan } \\
\text { proses } \\
\text { pikir/delusi } \\
\text { Halusinasi } \\
\text { Tidak mampu } \\
\text { mengalami } \\
\text { emosi } \\
\text { Perilaku tidak } \\
\text { terorganisir } \\
\text { Isolasi social }\end{array}$ \\
\hline
\end{tabular}

\section{Respon Adaptif}

Respon adaptif adalah respon yang dapat diterima norma-norma sosial budaya yang berlaku. Dengan kata lain individu tersebut dalam batas normal jika menghadapi suatu masalah akan dapat memecahkan masalah tersebut, respon adaptif:

a. Pikiran logis adalah pandangan yang mengarah pada kenyataan.

b. Persepsi akurat adalah pandangan yang tepat pada kenyataan.

c. Emosi konsisten dengan pengalaman yaitu perasaan yang timbul dari pengalaman.

d. Perilaku sosial adalah sikap dan tingkah laku yang masih dalam batas kewajaran.

e. Hubungan sosial adalah proses suatu interaksi dengan orang lain dan lingkungan

\section{Respon Psikososial}

Respon psikosial meliputi: 
a. Proses pikir terganggu adalah proses pikir yang menimbulkan gangguan.

b. Ilusi adalah interpretasi atau penilaian yang salah tentang penerapan yang benar-benar terjadi (objek nyata) karena rangsangan panca indera.

c. Emosi berlebihan atau berkurang.

d. Perilaku tidak biasa adalah sikap dan tingkah laku yang melebihi batas kewajaran.

e. Menarik diri adalah percobaan untuk menghindar interaksi dengan orang lain.

\section{Respon Maladaptif}

Respon maladaptif adalah respon individu dalam menyelesaikan masalah yang menyimpang dari norma-norma sosial budaya dan lingkungan, adapun respon maladaptif meliputi:

a. Kelainan pikiran adalah keyakianan yang secara kokoh dipertahankan walaupun tidak diyakini oleh orang lain dan bertetangan dengan kenyataan sosial.

b. Halusinasi merupakan persepsi sensori yang salah atau persepsi eksternal yang tidak realita atau tidak ada.

c. Kerusakan proses emosi adalah perubahan sesuatu yang timbul dari hati.

d. Perilaku tidak terorganisir merupakan suatu yang tidak teratur.

e. Isolasi sosial adalah kondisi kesendirian yang dialami oleh individu dan diterima sebagai ketentuan oleh orang lain dan sebagai suatu kecelakaan yang negatif mengancam. 


\subsubsection{Fase Halusinasi}

Halusinasi terbagi atas beberapa fase (Oktiviani, 2020), yaitu :

a. Fase Pertama / Sleep disorder

pada fase ini Klien merasa banyak masalah, ingin menghindar dari lingkungan, takut diketahui orang lain bahwa dirinyabanyak masalah. Masalah makin terasa sulit karna berbagai stressor terakumulasi, misalnya kekasih hamil, terlibat narkoba, dikhianati kekasih, masalah dikampus, drop out, dst. Masalah terasa menekan karena terakumulasi sedangkan support sistem kurang dan persepsi terhadap masalah sangat buruk. Sulit tidur berlangsung trus-menerus sehingga terbiasa menghayal. Klien menganggap lamunanlamunan awal tersebut sebagai pemecah masalah

b. Fase Kedua / Comforting

Klien mengalami emosi yang berlanjut seperti adanya perasaan cemas, kesepian, perasaan berdosa, ketakutan, dan mencoba memusatkan pemikiran pada timbulnya kecemasan. Ia beranggapan bahwa pengalaman pikiran dan sensorinya dapat dia kontrol bila kecemasannya diatur, dalam tahap ini ada kecenderungan klien merasa nyaman dengan halusinasinya

c. Fase Ketiga / Condemning

Pengalaman sensori klien menjadi sering datang dan mengalami bias.

Klien mulai merasa tidak mampu lagi mengontrolnya dan mulai berupaya menjaga jarak antara dirinya dengan objek yang dipersepsikan klien mulai menarik diri dari orang lain, dengan intensitas waktu yang lama.

d. Fase Keempat / Controlling Severe Level of Anxiety

Klien mencoba melawan suara-suara atau sensori abnormal yang datang. Klien dapat merasakan kesepian bila halusinasinya berakhir. Dari sinilah dimulai fase gangguan psikotik.

e. Fase ke lima / Conquering Panic Level of Anxiety Pengalaman sensorinya terganggu. Klien mulai terasa terancam dengan datangnya suara-suara terutama bila klien tidak dapat 


\subsubsection{Tanda dan Gejala}

Tanda dan gejala halusinasi dinilai dari hasil observasi terhadap pasien serta ungkapan pasien. Menurut (Keliat, 2014), tanda dan gejala pasein halusinasi adalah sebagai berikut :

Data Objektif

1. Bicara atau tertawa sendiri

2. Marah-marah tanpa sebab

3. Memalingkan muka ke arah telinga seperti mendengar sesuatu

4. Menutup telinga

5. Menunjuk ke arah tertentu

6. Ketakutan pada sesuatu yang tidak jelas

7. Mencium sesuatu seperti sedang membaui bau-bauan tertentu

8. Menutup hidung

9. Sering meludah

10. Muntah

11. Menggaruk-garuk permukaan kulit

Data Subjektif : Pasien mengatakan

1. Mendengar suara-suara atau kegaduhan

2. Mendengar suara yang mengajak bercakap-cakap

3. Mendengar suara menyuruh melakukan sesuatu yang berbahaya

4. Melihat bayangan, sinar, bentuk geometris, bentuk kartun, melihat hantu atau monster

5. Mencium bau-bauan seperti bau darah, urin, feses, kadangkadang bau menyenangkan

6. Merasakan rasa seperti darah, urin atau feses

7. Merasa takut atau senang dengan halusinasinya

8. Mengatakan sering mendengar sesuatu pada waktu tertentu saaat sedang sendirian

9. Mengatakan sering mengikuti isi perintah halusinasi 


\subsection{Konsep Dasar Asuhan Keperawatan}

\subsubsection{Pengkajian Keperawatan}

Menurut Keliat (2014). Bahwa faktor-faktor terjadinya halusinasi meliputi:

1. Faktor predisposisi

Faktor predisposisi atau faktor yang mendukung terjadinya halusinasi menurut Keliat (2014) adalah :

a. Faktor biologis

Pada keluarga yang melibatkan anak kembar dan anak yang diadopsi menunjukkan peran genetik pada schizophrenia.Kembar identik yang dibesarkan secara terpisah mempunyai angka kejadian schizophrenia lebih tinggi dari pada saudara sekandung yang dibesarkan secara terpisah.

b. Faktor psikologis

Hubungan interpersonal yang tidak harmonis akan mengakibatkan stress dan kecemasan yang berakhir dengan gangguan orientasi realita.

c. Faktor sosial budaya

Stress yang menumpuk awitan schizophrenia dan gangguan psikotik lain, tetapi tidak diyakini sebagai penyebab utama gangguan.

2. Faktor presipitasi

Faktor presipitasi atau faktor pencetus halusinasi menurut Keliat (2014) adalah:

a. Biologis

Stressor biologis yang berhubungan dengan respon neurobiologis maladaptif adalah gangguan dalam komunikasi dan putaran umpan balik otak dan abnormalitas pada mekanisme pintu masuk dalam otak, yang mengakibatkan ketidakmampuan untuk secara selektif menanggapi stimulus. 


\section{b. Lingkungan}

Ambang toleransi terhadap stres yang ditentukan secara biologis berinteraksi dengan stresor lingkungan untuk menentukan terjadinya gangguan prilaku.

c. Stres sosial / budaya

Stres dan kecemasan akan meningkat apabila terjadi penurunan stabilitas keluarga, terpisahnya dengan orang terpenting atau disingkirkan dari kelompok.

d. Faktor psikologik

Intensitas kecemasan yang ekstrem dan memanjang disertai terbatasnya kemampuan mengatasi masalah dapat menimbulkan perkembangan gangguan sensori persepsi halusinasi.

e. Mekanisme koping

Menurut Keliat (2014) perilaku yang mewakili upaya untuk melindungi pasien dari pengalaman yang menakutkan berhubungan dengan respons neurobiologis maladaptif meliputi : regresi, berhunbungan dengan masalah proses informasi dan upaya untuk mengatasi ansietas, yang menyisakan sedikit energi untuk aktivitas seharihari. Proyeksi, sebagai upaya untuk menejlaskan kerancuan persepsi dan menarik diri.

f. Sumber koping

Menurut Keliat (2014) sumber koping individual harus dikaji dengan pemahaman tentang pengaruh gangguan otak pada perilaku. Orang tua harus secara aktif mendidik anakanak dan dewasa muda tentang keterampilan koping karena mereka biasanya tidak hanya belajar dari pengamatan. Disumber keluarga dapat pengetahuan tentang penyakit, finensial yang cukup, faktor ketersediaan waktu dan tenaga serta kemampuan untuk memberikan dukungan secara berkesinambungan. 


\section{g. Perilaku halusinasi}

Menurut Keliat (2014), batasan karakteristik halusinasi yaitu bicara teratawa sendiri, bersikap seperti memdengar sesuatu, berhenti bicara ditengah - tengah kalimat untuk mendengar sesuatu, disorientasi, pembicaraan kacau dan merusak diri sendiri, orang lain serta lingkungan.

\subsubsection{Diagnosa Keperawatan}

Menurut NANDA (2015-2017) yakni gangguan persepsi sensori halusinasi pendengaran. Dengan faktor berhubungan dan batasan karakteristik disesuaikan dengan keadaan yang ditemukan pada tiap-tiap partisipan. Topik yang diteliti yakni kemampuan mengontrol halusinasi penedengaran (Aji, 2019).

\subsubsection{Tindakan Keperawatan}

Menurut Pima (2020) tindakan keperawatan pada klien halusinasi terdiri dari :

a. Tindakan keperawatan untuk klien meliputi :

b. Membantu klien untuk mengenali halusinasi

c. Melatih klien mengontrol halusinasinya dengan cara menghardik halusinasi

d. Menggunakan obat secara teratur

e. Bercakap-cakap dengan orang lain

Rencana tindakan pada keluarga (Keliat, 2014) adalah

1. Diskusikan masalah yang dihadap keluarga dalam merawat pasien

2. Berikan penjelasan meliputi : pengertian halusinasi, proses terjadinya halusinasi, jenis halusinasi yang dialami, tanda dan gejala halusinasi, proses terjadinya halusinasi.

3. Jelaskan dan latih cara merawat anggota keluarga yang mengalami 
halusinasi : menghardik, minum obat, bercakap-cakap, melakukan aktivitas.

4. Diskusikan cara menciptakan lingkungan yang dapat mencegah terjadinya halusinasi.

5. Diskusikan tanda dan gejala kekambuhan

6. Diskusikan pemanfaatan fasilitas pelayanan kesehatan terdekat untuk follow up anggota keluarga dengan halusinasi.

\subsubsection{Penatalaksanaan Medis}

Halusinasi merupakan salah satu gejala yang paling sering terjadi pada gangguan Skizofrenia. Dimana Skizofrenia merupakan jenis psikosis, adapun tindakan penatalaksanaan dilakukan dengan berbagai terapi yaitu dengan:

1. Psikofarmakologis

Obat sangat penting dalam pengobatan skizofrenia, karena obat dapat membantu pasien skizofrenia untuk meminimalkan gejala perilaku kekerasan, halusinasi, dan harga diri rendah. Sehingga pasien skizofrenia harus patuh minum obat secara teratur dan mau mengikuti perawatan (Pardede, Keliat, Wardani, 2013):

a. Haloperidol (HLD)

Obat yang dianggap sangat efektif dalam pengelolaan hiperaktivitas, gelisah, agresif, waham, dan halusinasi.

b. Chlorpromazine (CPZ)

Obat yang digunakan untuk gangguan psikosis yang terkait skizofrenia dan gangguan perilaku yang tidak terkontrol

c. Trihexilpenidyl (THP)

Obat yang digunakan untuk mengobati semua jenis parkinson dan pengendalian gejala ekstrapiramidal akibat terapi obat.

1) Dosis

- Haloperidol 3x5 mg (tiap 8 jam) intra muscular. 
- Clorpromazin 25-50 mg diberikan intra muscular setiap 6-8 jam sampai keadaan akut teratasi.

2) Dalam keadaan agitasi dan hiperaktif diberikan tablet:

- Haloperidol 2x1,5 - 2,5 mg per hari.

- Klorpromazin 2x100 mg per hari

- Triheksifenidil $2 \times 2 \mathrm{mg}$ per hari

3) Dalam keadaan fase kronis diberikan tablet:

- Haloperidol 2x0,5 - $1 \mathrm{mg}$ perhari

- Klorpromazin 1x50 mg sehari (malam)

- Triheksifenidil 1-2x2 mg sehari

\section{Psikosomatik}

Terapi kejang listrik (Electro Compulsive Therapy), yaitu suatu terapi fisik atau suatu pengobatan untuk menimbulkan kejang grand mal secara artifisial dengan melewatkan aliran listrik melalui elektroda yang dipasang pada satu atau dua temples pada pelipis. Jumlah tindakan yang dilakukan merupakan rangkaian yang bervariasi pada setiap pasien tergantung pada masalah pasien dan respon terapeutik sesuai hasil pengkajian selama tindakan. Pada pasien Skizofrenia biasanya diberikan 30 kali. ECT biasanya diberikan 3 kali seminggu walaupun biasanya diberikan jarang atau lebih sering. Indikasi penggunaan obat: penyakit depresi berat yang tidak berespon terhadap obat, gangguan bipolar di mana pasien sudah tidak berespon lagi terhadap obat dan pasien dengan bunuh diri akut yang sudah lama tidak mendapatkan pertolongan. 


\section{Psikoterapi}

Membutuhkan waktu yang relatif lama, juga merupakan bagian penting dalam proses terapeutik. Upaya dalam psikoterapi ini meliputi: memberikan rasa aman dan tenang, menciptakan lingkungan terapeutik, memotivasi klien untuk dapat mengungkapkan perasaan secara verbal, bersikap ramah, sopan, dan jujur terhadap klien.

\subsubsection{Pelaksanaan Keperawatan}

Implementasi disesuaikan dengan rencana tindakan keperawatan. Pada situasi nyata sering pelaksanaan jauh berbeda dengan rencana, hal ini terjadi karena perawat belum terbiasa menggunakan rencana tertulis dalam melaksanakan tindakan keperawatan. Sebelum melaksanakan tindakan keperawatan yang sudah direncanakan, perawat perlu memvalidasi dengan singkat apakah rencana tindakan masih sesuai dan dibutuhkan klien sesuai dengan kondisinya (here and now). Perawat juga menilai diri sendiri, apakah kemampuan interpersonal, intelektual, tekhnikal sesuai dengan tindakan yang akan dilaksanakan, dinilai kembali apakah aman bagi klien. Setelah semuanya tidak ada hambatan maka tindakan keperawatan boleh dilaksanakan.

Adapun pelaksanaan tindakan keperawatan jiwa dilakukan berdasarkan Strategi Pelaksanaan (SP) yang sesuai dengan masingmasing masalah utama. Pada masalah gangguan sensori persepsi: halusinasi pendengaran, terdapat 2 jenis SP, yaitu SP Klien dan SP Keluarga.

SP klien terbagi menjadi SP 1 (membina hubungan saling percaya, mengidentifikasi halusinasi "jenis, isi, waktu, frekuensi, situasi, perasaan dan respon halusinasi”, mengajarkan cara menghardik, memasukan cara menghardik ke dalam jadwal; SP 2 (mengevaluasi SP 1, mengajarkan cara minum obat secara teratur, memasukan ke 
dalam jadwal); SP 3 (mengevaluasi SP 1 dan SP 2, menganjurkan klien untuk mencari teman bicara); SP 4 (mengevaluasi SP 1, SP 2, dan SP 3, melakukan kegiatan terjadwal).

SP keluarga terbagi menjadi SP 1 (membina hubungan saling percaya, mendiskusikan masalah yang dihadapi keluarga dalam merawat pasien, menjelaskan pengertian, tanda dan gejala helusinasi, jenis halusinasi yang dialami klien beserta proses terjadinya, menjelaskan cara merawat pasien halusinasi); SP 2 (melatih keluarga mempraktekan cara merawat pasien dengan halusinasi, melatih keluarga melakukan cara merawat langsung kepada pasien halusinasi); SP 3 (membantu keluarga membuat jadwal aktivitas di rumah termasuk minum obat (discharge planing), menjelaskan follow up pasien setelah pulang).

Pada saat akan dilaksanakan tindakan keperawatan maka kontrak dengan klien dilaksanakan dengan menjelaskan apa yang akan dikerjakan dan peran serta klien yang diharapkan, dokumentasikan semua tindakan yang telah dilaksanakan serta respon klien.

\subsubsection{Evaluasi Keperawatan}

Evaluasi adalah proses yang berkelanjutan untuk menilai efek dari tindakan keperawatan pada klien (Dalami, 2009). Evaluasi dilakukan terus menerus pada respon klien terhadap tindakan yang telah dilaksanakan, evaluasi dapat dibagi dua jenis yaitu: evaluasi proses atau formatif dilakukan selesai melaksanakan tindakan. Evaluasi hasil atau sumatif dilakukan dengan membandingkan respon klien pada tujuan umum dan tujuan khusus yang telah ditentukan.

Evaluasi keperawatan yang diharapkan pada pasien dengan gangguan sensori persepsi: halusinasi pendengaran adalah: tidak 
terjadi perilaku kekerasan, klien dapat membina hubungan saling percaya, klien dapat mengenal halusinasinya, klien dapat mengontrol halusinasinya, klien mendapatkan dukungan dari keluarga dalam mengontrol halusinasinya, klien dapat menggunakan obat dengan baik dan benar. 


\section{BAB III}

\section{TINJAUAN KASUS}

\subsection{Identitas Klien}

$\begin{array}{ll}\text { Inisial } & : \text { Ny. T } \\ \text { Tanggal Masuk } & : \text { 17 Juni } 2015 \\ \text { Umur } & : 52 \text { Tahun } \\ \text { Agama } & : \text { Budha } \\ \text { Informan } & : \text { Klien dan Status Klien }\end{array}$

\subsection{Alasan Masuk}

Klien suka menyendiri, melamun, mondar -mandir,mendengar suara-suara tanpa wujud.

\subsection{Faktor Predisposisi}

Klien sebelumnya pernah mengalami gangguan jiwa \pm 5 Tahun yang lalu tepatnya pada tahun 2015. Klien, suka menyendiri, melamun, sering bicara sendiri, mondar mandir, mendengar suara-suara tanpa wujud, tertawa sendiri akhirnya keluarga membawa klien. Keluarga klien tidak ada yang pernah mengalami gangguan jiwa klen juga mengalami juga gagal dalam berhubungan suami istri, di mana suaminya menceraikan klien dalam keadaan hamil.

Masalah Keperawatan : Halusinasi

\subsection{Fisik}


Klien tidak memiliki keluhan fisik, saat dilakukan pemeriksaan tandatanda vital, didapatkan hasil TD : $120 / 80 \mathrm{mmHg} ; \mathrm{N}: 82 \mathrm{x} / \mathrm{i} ; \mathrm{S}: 36,5^{\circ} \mathrm{C} ; \mathrm{P}$ : 20x/i. Klien memiliki tinggi badan $162 \mathrm{~cm}$ dan berat badan $60 \mathrm{Kg}$.

\subsection{Psikososial}

\subsubsection{Genogram}
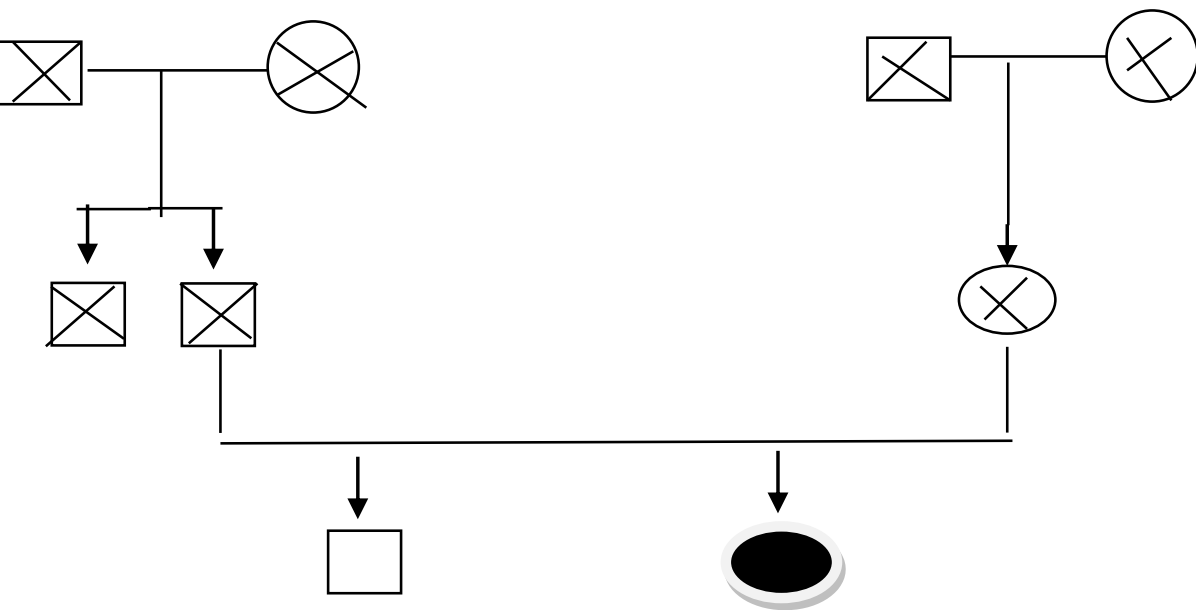

Penjelasan :

Klien merupakan anak kedua dari 2 bersaudara ,klien memiliki 1 saudara laki-laki. Klien sudah menikah namun sudah bercerai tapi belum mempunyai anak. Dan sebelumnya klien tinggal di rumah saudaranya laki-laki.

Keterangan :

$\square \quad$ : Laki-laki

$\bigcirc$ : Perempuan

: Klien

---- $\quad$ : Tinggal dalam satu rumah

$\searrow$ : meninggal 


\subsubsection{Konsep diri}

a. Gambaran diri :Klien menyukai seluruh tubuhnya dan tidak ada yang cacat

b. Identitas :Klien anak ke 3 dari 3 bersaudara, klien hanya lulusan SMA yang saat ini tidak memiliki pekerjaan

c. Peran : Klien berperan sebagai anak

d. Ideal diri :Klien merasa malu karena klien galgal dalam asmarnya .

e. Harga diri :Klien mengatakan merasa malu karena gagal dama menjalin asmaranya dengan kekasihnya.

\subsubsection{Hubungan social}

Klien mengganggap bahwa keluarganya adalah orang yang sangat berarti dalam hidupnya, terutama orangtuanya. Klien tidak mengikuti kegiatan di kelompok/masyarakat. Klien mengatakan mempunyai hambatan dalam berhubungan dengan orang lain karena klien sulit bergaul dan selalu ingin menyendiri.

Masalah keperawatan: Isolasi Sosial: Menarik diri

\subsubsection{Spiritual}

a. Nilai dan Keyakinan :Klien beragama Budha dan yakin dengan agamanya.

b. Kegiatan Ibadah :Klien ikut melakukan ibadah selama dirawat.

\subsubsection{Status Mental}

1. Penampilan

Klien tampak rapi dalam berpakaian

2. Pembicaraan

Klien masih mampu menjawab pertanyaan perawat dengan lambat namun dapat dipahami 
3. Aktivitas Motorik

Klien mengatakan bisa melakukan aktivitas sehari - hari.

4. Suasana perasaan

Klien sedih karena tinggal di yayasan

Masalah keperawatan :Harga Diri Rendah

5. Afek

afek wajah sesuai dengan topic pembicaraan

6. Interaksi selama wawancara

Klien kooperatif saat wawancara

7. Persepsi

Klien mengatakan bahwa ia mendengar ada suara-suara

Masalah keperawatan : Gangguan persepsi sensori : halusinasi

8. Proses Pikir

Klien mampu menjawab apa yang ditanya dengan baik.

9. Isi piker

Klien dapat mengontrol isi pikirnya,klien tidak mengalami gangguan isi pikir dan tidak ada waham. Klien tidak mengalami fobia, obsesi ataupun depersonalisasi.

10. Tingkat kesadaran

Klien tidak mengalami gangguan orientasi, klien mengenali waktu, orang dan tempat.

11. Memori

Klien mampu menceritakan kejadian di masa lalu dan yang baru terjadi.

12. Tingkat konsentrasi berhitung

Klien mampu berkonsentrasi dalam perhitungan sederhana tanpa bantuan orang lain.I

13. Kemampuan penilaian

Klien dapat membedakan hal yang baik dan yang buruk (mampu melakukan penilaian)

14. Daya tilik diri 
Klien tidak mengingkari penyakit yang diderita, klien mengetahui bahwa dia sedang sakit dan dirawat di rumah sakit jiwa.

\subsection{Mekanisme Koping}

Klien mengalami mekanisme koping adaptif yaitu klien dapat berbicara baik dengan orang lain.

\subsection{Masalah Psikososial dan Lingkungan}

Klien mengatakan sulit berteman dengan orang lain karena klien selalu ingin menyendiri.

\subsection{Pengetahuan Kurang Tentang Gangguan Jiwa}

Klien tidak mengetahui tentang gangguan jiwa yang di alaminya dan obat yang dikonsumsinya.

\subsection{Aspek Medik}

Diagnosa medis : Skizofrenia Paranoid

Terapi medis yang diberikan:
a. Resperidon tablet $2 \mathrm{mg} 2 \mathrm{x} 1$
b. Chlozapine tablet $25 \mathrm{mg} 1 \times 1$
c. THP (trihexyphenidyl) $2 \mathrm{mg} 2 \mathrm{X} 1$ 


\subsection{Analisa Data}

\begin{tabular}{|c|c|c|}
\hline No & Data & Masalah Keperawatan \\
\hline 1 & $\begin{array}{l}\text { DS: } \\
\text { - Klien merasa tidak berguna karena tidak dapat membantu keluarga. } \\
\text { - Klien sedih berada di Yayasan Pemenang Jiwa } \\
\text { - Klien merasa malu karena gagal dalam pernikahannya. } \\
\text { DO: } \\
\text { - klien tampak murung } \\
\text { - lebih banyak diam } \\
\text { - nada bicara pelan }\end{array}$ & $\begin{array}{l}\text { Gangguan konsep diri : Harga diri } \\
\text { rendah kronis }\end{array}$ \\
\hline 2 & 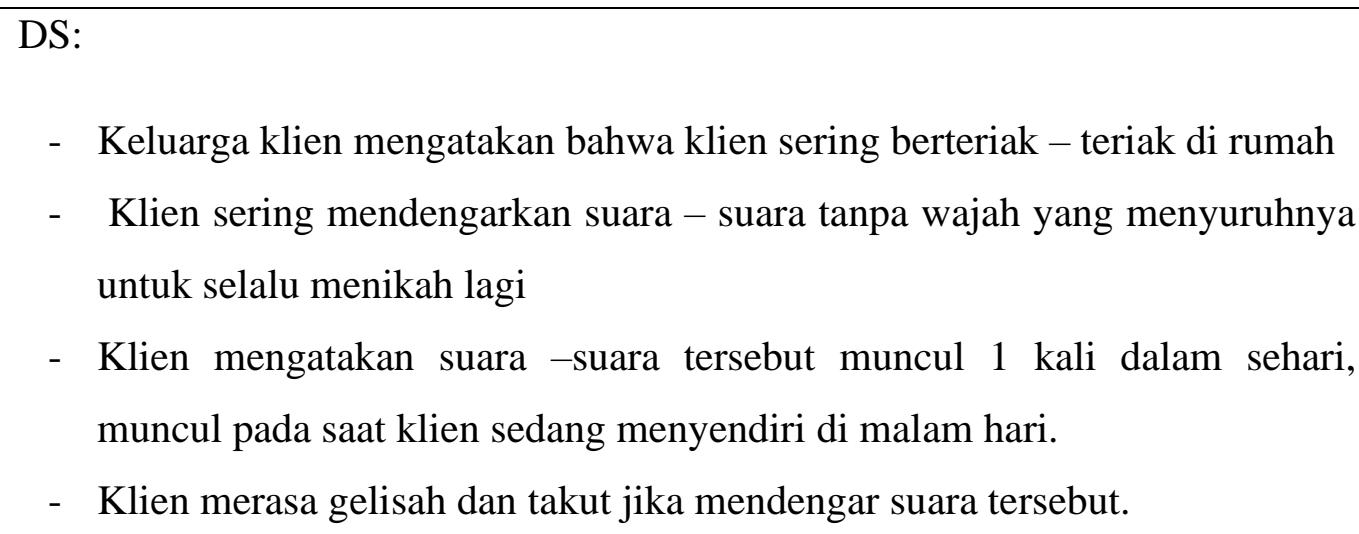 & $\begin{array}{l}\text { Gangguan Persepsi Sensori : Halusinasi } \\
\text { Pendengaran }\end{array}$ \\
\hline
\end{tabular}




\begin{tabular}{|l|l|l|}
\hline & $\begin{array}{l}\text { DO: } \\
\text { Klien sering marah-marah, mondar-mandir, berbicara sendiri, berbicara } \\
\text { ngawur, sering senyum-senyum sendiri. }\end{array}$ & \\
\hline 3 & DS : & Isolasi sosial : Menarik diri \\
& $-\quad$ Klen jarang mengikuti kegiatan di keleompok di masyarakat \\
$-\quad$ Klien mengatakan mempunyai hambatan dengan orang lain & \\
& $\begin{array}{l}\text { DO : } \\
-\quad \text { Klien menyendiri suka menyendiri } \\
-\quad \text { Klen Tidak mau berintraksi dengan orang lain } \\
-\quad \text { Klen jarang berkumpul dengan orang lain }\end{array}$ & \\
\hline
\end{tabular}

\subsection{Pohon Masalah}

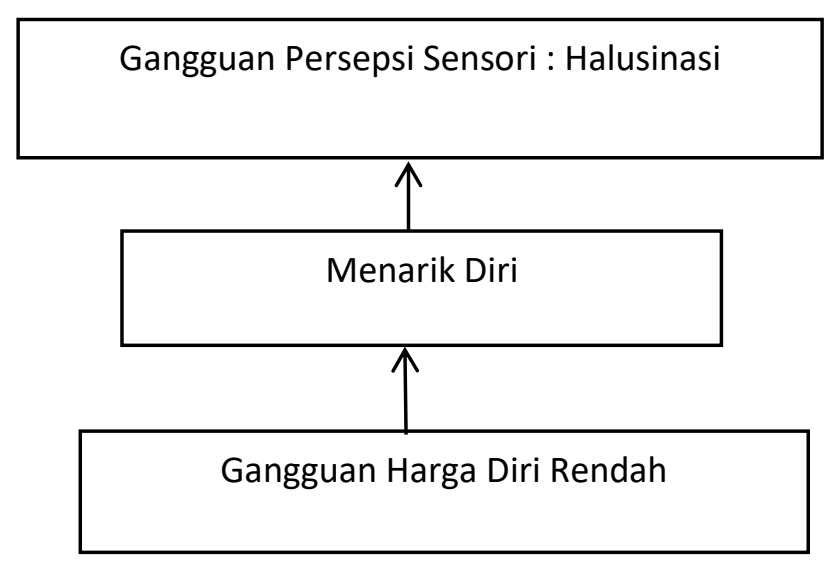




\subsection{Prioritas Diagnosa Keperawatan}

- Gangguan persepsi Sensorik : Halusinasi pendengaran

\subsection{Intervensi Keperawatan}

\begin{tabular}{|c|c|c|}
\hline No & Diagnosa & Intervensi \\
\hline 1. & $\begin{array}{l}\text { Gangguan Persepsi Sensori : Halusinasi Pendengaran } \\
\text { DO: } \\
\text { - Klien sering, mondar - mandir, berbicara sendiri, berbicara } \\
\text { ngawur, sering senyum-senyum sendiri. } \\
\text { DS: } \\
\text { - Keluarga klien mengatakan bahwa klien sering berteriak - } \\
\text { teriak di yayasan } \\
\text { - Klien sering mendengarkan suara - suara tanpa wajah yang } \\
\text { menyuruhnya untuk bebicara bicara sendiri } \\
\text { - Klien mengatakan suara - suara tersebut muncul } 2 \text { kali/ hari, } \\
\text { muncul pada saat melamun } \\
\text { - Klien merasa gelisah dan takut jika mendengar suara tersebut. }\end{array}$ & $\begin{array}{l}\text { SP 1: } \\
\text { 1. Identifikasi isi, waktu terjadi, situasi pencetus, dan } \\
\quad \text { respon terhadap halusinasi } \\
\text { 2. Jelaskan dan Latih teknik menghardik } \\
\text { SP 2: } \\
\text { Kontrol Halusinasi klien dengan minum obat secara teratur } \\
\text { SP 3: } \\
\text { Ajarkan cara mengontrol halusinasi dengan bercakap - } \\
\text { cakap dengan orang lain }\end{array}$ \\
\hline
\end{tabular}




\begin{tabular}{|c|c|c|}
\hline & & $\begin{array}{l}\text { SP 4: } \\
\text { Ajarkan cara mengontrol halusinasi dengan melakukan } \\
\text { kegiatan terjadwal }\end{array}$ \\
\hline 2. & 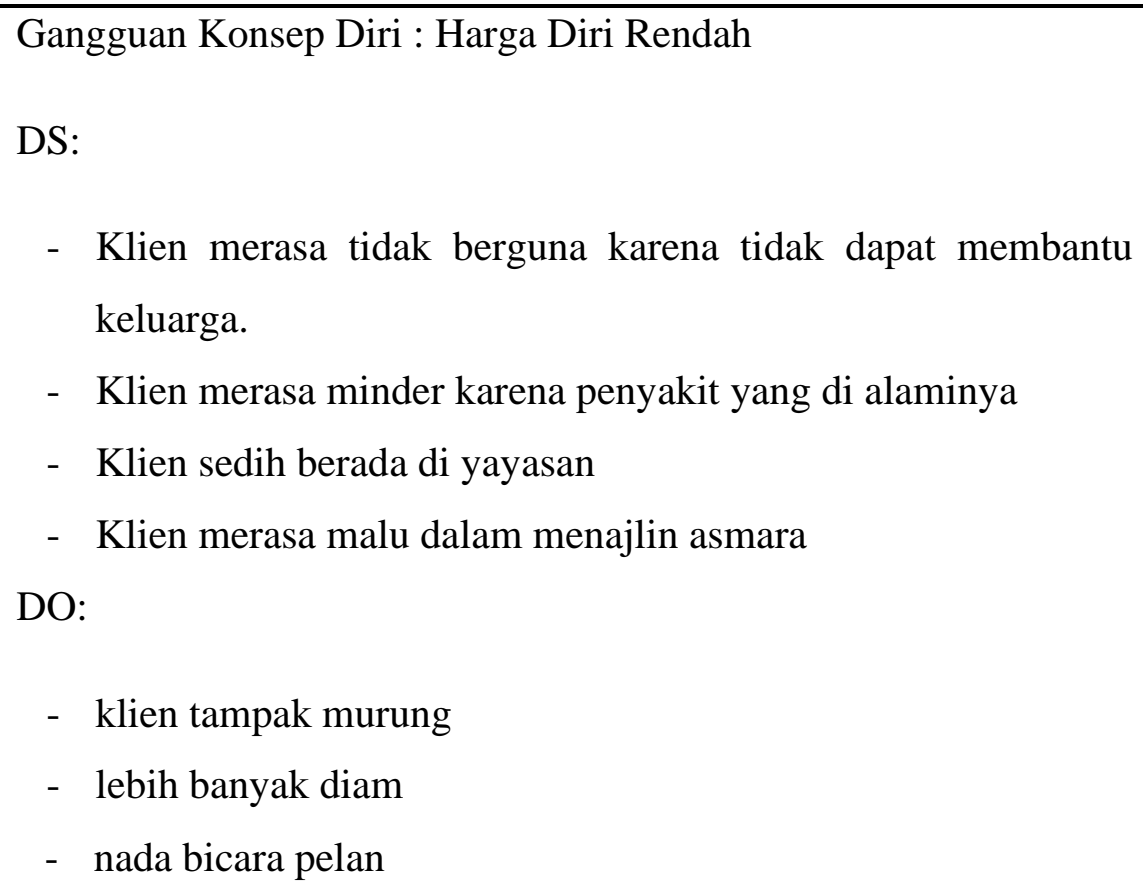 & $\begin{array}{l}\text { SP 1: } \\
\text { Identifikasi Kemampuan dan aspek yang di miliki klien } \\
\text { SP 2: } \\
\text { Latih kegiatan sesuai kemampuan yang dipilih pertama } \\
\text { SP 3: } \\
\text { Latih kegiatan sesuai kemampuan yang dipilih kedua } \\
\text { SP 4: } \\
\text { Latih kegiatan sesuai kemampuan yang dipilih ketiga }\end{array}$ \\
\hline 3 & $\begin{array}{l}\text { DS : } \\
\text { - Klen jarang mengikuti kegiatan di keleompok di }\end{array}$ & SP 1: \\
\hline
\end{tabular}




\begin{tabular}{l|l|l|}
$\quad$ masyarakat. & Menjelaskan keuntungan dan kerugian mempunyai teman \\
- Kilen mengatakan mempunyai hambatan dengan orang lain. & SP 2 : \\
DO : & Melatih klen berkenalam dengan 2 orang atau lebih \\
- Klien menyendiri & SP 3 : \\
- Klen Tidak mau berintraksi dengan orang lain & Melatih bercakap cakap sembil melakukan kegiatan harian \\
- Klen jarang berkumpul dengan orang lain & SP 4 : \\
& Melatih berbicara sosial, meminta sesuatu, berbelanja dan \\
sebagainya
\end{tabular}




\subsection{IMPLEMENTASI \& EVALUASI}

\begin{tabular}{|c|c|c|}
\hline WAKTU & IMPLEMENTASI & EVALUASI \\
\hline $\begin{array}{l}\text { Senin,15 } \\
\text { Februari } \\
2021 \\
\text { Jam } 11.00 \\
\text { wib }\end{array}$ & $\begin{array}{l}\text { 1. Data } \\
\text { - } \quad \text { Klien sering, mondar - mandir, berbicara sendiri, berbicara } \\
\text { ngawur, sering senyum-senyum sendiri, sering mengarahkan } \\
\text { telinganya ke tempat - tempat tertentu. } \\
\text { - } \text { Klien sering mendengarkan suara - suara tanpa wajah yang } \\
\text { menyuruhnya untuk berbicara bicara sendiri. } \\
\text { - } \quad \text { Klien mengatakan suara - suara tersebut muncul 1 kali/ hari, } \\
\text { muncul pada saat melamun } \\
\text { - Klien merasa gelisah dan takut jika mendengar suara tersebut. } \\
\text { 2. Diagnosa Keperawatan } \\
\text { Gangguan sensori persepsi : halusinasi pendengaran } \\
\text { 3. Intervensi Keperawatan } \\
\text { SP } 1 \text { a } \\
\text { a. Identifikasi jenis halusinasi }\end{array}$ & $\begin{array}{l}\text { S : Senang } \\
\text { O : } \\
\text {-klien mampu mengenali halusinasinya dengan } \\
\text { mandiri } \\
\text {-klien mampu menghardik halusinasinya dengan } \\
\text { motivasi perawat } \\
\text { A : Halusinasi pendengaran (+) } \\
\text { P : } \\
\text { - Latihan mengidentifikasi halusinasi :isi, } \\
\quad \text { frekuensi, waktu terjadi, situasi pencutus, } \\
\text { perasaan dan respon halusinasi. }\end{array}$ \\
\hline
\end{tabular}




\begin{tabular}{|l|l|}
\hline b. Identifikasi isi halusinasi \\
c. Identifikasi waktu halusinasi \\
d. Identifikasi frekuensi halusinasi \\
e. Identifikasi situasi yang menyebabkan halusinasi \\
f. Identifikasi respon klien terhadap halusinasi \\
g. Latih cara mengontrol halusinasi dengan menghardik \\
4. Implementasi Keperawatan \\
a. Mengidentifikasijenis halusinasi \\
b. Mengidentifikasi isi halusinasi \\
c. Mengidentifikasi waktu halusinasi \\
d. Mengidentifikasi frekuensi halusinasi \\
f. Mengidentifikasi situasi yang menyebabkan halusinasi \\
g. Melatih cara mengontrol halusinasi dengan menghardik \\
Rencana Tindak Lanjut : SP 2 (Latih cara minum obat secara teratur.
\end{tabular} \mid




\begin{tabular}{|c|c|c|}
\hline $\begin{array}{l}\text { Selasa, } 12 \\
\text { Februari } \\
2021 \\
\text { Jam } 11.00 \\
\text { wib }\end{array}$ & $\begin{array}{l}\text { 1. Data } \\
\text { - Klien mengatakan mendengar suara-suara tersebut namun sudah } \\
\text { bisa mengendalikan suara-suara tersebut dengan cara } \\
\text { menghardik dan bercakap-cakap dengan orang lain. Klien juga } \\
\text { mau melakukan aktivitas sesuai dengan jadwal yang sudah } \\
\text { disusun } \\
\text { - Klien masih nampak berbicara sendiri sesekali } \\
\text { 2. Diagnosa Keperawatan } \\
\text { Gangguan sensori persepsi : halusinasi pendengaran } \\
\text { 3. Intervensi Keperawatan } \\
\text { SP } 2 \\
\text { Latih cara minum obat dengan prinsip } 6 \text { benar } \\
\text { 4. Implementasi Keperawatan } \\
\text { Melatih cara minum obat dengan prinsip } 6 \text { benar } \\
\text { Rencana Tindak Lanjut : SP } 3\end{array}$ & $\begin{array}{l}\text { S : Klien senang dan antusias. } \\
\text { O: Klien mampu mengontrol halusinasi dengan } \\
\text { minum obat } 2 \text { kali dalam sehari. } \\
\text { A: Halusinasi pendengaran (+) } \\
\text { P: } \\
\text { - Latihan mengidentifikasi halusinasi : isi, } \\
\text { frekuensi, waktu terjadi, situasi pencetus, } \\
\text { perasaan dan respon halusinasi } \\
\text { - Latihan menghardik halusinasi } 3 \text { kali } \\
\text { sehari } \\
\text { - Latihan minum obat dengan prinsip } 6 \\
\text { benar } 2 \text { kali sehari }\end{array}$ \\
\hline
\end{tabular}




\begin{tabular}{|c|c|c|}
\hline & $\begin{array}{l}\text { (mengendalikan halusinasi dengan bercakap-cakap dengan } \\
\text { orang lain) }\end{array}$ & \\
\hline $\begin{array}{l}\text { Rabu, } 17 \\
2020\end{array}$ & $\begin{array}{l}\text { 1. Data } \\
\text { - Klien mengatakan mendengar suara-suara yang isinya “ } \\
\text { Menikah lagi” } \\
\text { - Klien mengatakan Suara-suara itu muncul waktu malam hari, } \\
\text { saat ingin tidur. } \\
\text { - Klien tampak bicara-bicara sendiri. Mulut klien tampak } \\
\text { komat-kamit. } \\
\text { 2. Diagnosa Keperawatan } \\
\text { Gangguan sensori persepsi : halusinasi pendengaran } \\
\text { 3. Intervensi Keperawatan } \\
\text { SP } 3 \text { mengendalikan halusinasi dengan bercakap-cakap } \\
\text { Latih dengan orang lain } \\
\text { 4. Implementasi Keperawatan } \\
\text { Melatih mengendalikan halusinasi dengan bercakap-cakap }\end{array}$ & $\begin{array}{l}\text { S : Klien dia merasa senang bisa bercakap- } \\
\text { cakap dengan orang lain } \\
\text { O : } \\
\text { - Klien nampak sesekali berbicara sendiri } \\
\text { dan menutup kupingnya (menghardik } \\
\text { halusinasi) } \\
\text { - Klien mempraktekkan cara bercakap-cakap } \\
\text { dengan orang lain } \\
\text { A : Halusinasi pendengaran (+) } \\
\text { P : } \\
\text { - Latihan menghardik halusinasi } 3 \text { kali } \\
\text { sehari } \\
\text { - Latihan minum obat dengan prinsip } 6 \\
\text { benar } 2 \text { kali sehari }\end{array}$ \\
\hline
\end{tabular}




\begin{tabular}{|c|c|c|}
\hline & $\begin{array}{l}\text { dengan orang lain } \\
\text { Rencana Tindak Lanjut : SP } 4 \\
\text { (Mengendalikan halusinasi dengan melakukan kegiatan yang biasa } \\
\text { dilakukan di yayasan) }\end{array}$ & $\begin{array}{l}\text { - Latihan bercakap-cakap dengan orang lain } \\
3 \text { kali sehari }\end{array}$ \\
\hline $\begin{array}{l}\text { Kamis, } 18 \\
\text { Februari } \\
2021 \text { pukul } \\
10.00 \text { WIB }\end{array}$ & $\begin{array}{l}\text { 1. Data } \\
\text { - Klien mengatakan masih mendengar suara-suara tersebut } \\
\text { namun sudah bisa mengendalikan suara-suara tersebut } \\
\text { dengan cara menghardik dan bercakap-cakap dengan orang } \\
\text { lain. Klien mengatakan mau melamun karena tidak ada } \\
\text { kegiatan. } \\
\text { - Klien tampak bicara-bicara sendiri. Mulut klien tampak } \\
\text { komat-kamit. } \\
\text { 2. Diagnosa Keperawatan } \\
\text { Gangguan sensori persepsi : halusinasi pendengaran } \\
\text { 3. Intervensi Keperawatan }\end{array}$ & $\begin{array}{l}\text { S : Klien mengatakan biasa memetik sayur dan } \\
\text { Menyusun piring. } \\
\text { O : } \\
\text { - Klien mampu melakukan kegiatan yang } \\
\text { biasa dilakukannya di Yayasan dan kegiatan } \\
\text { tersebut dijadwal }\end{array}$ \\
\hline
\end{tabular}




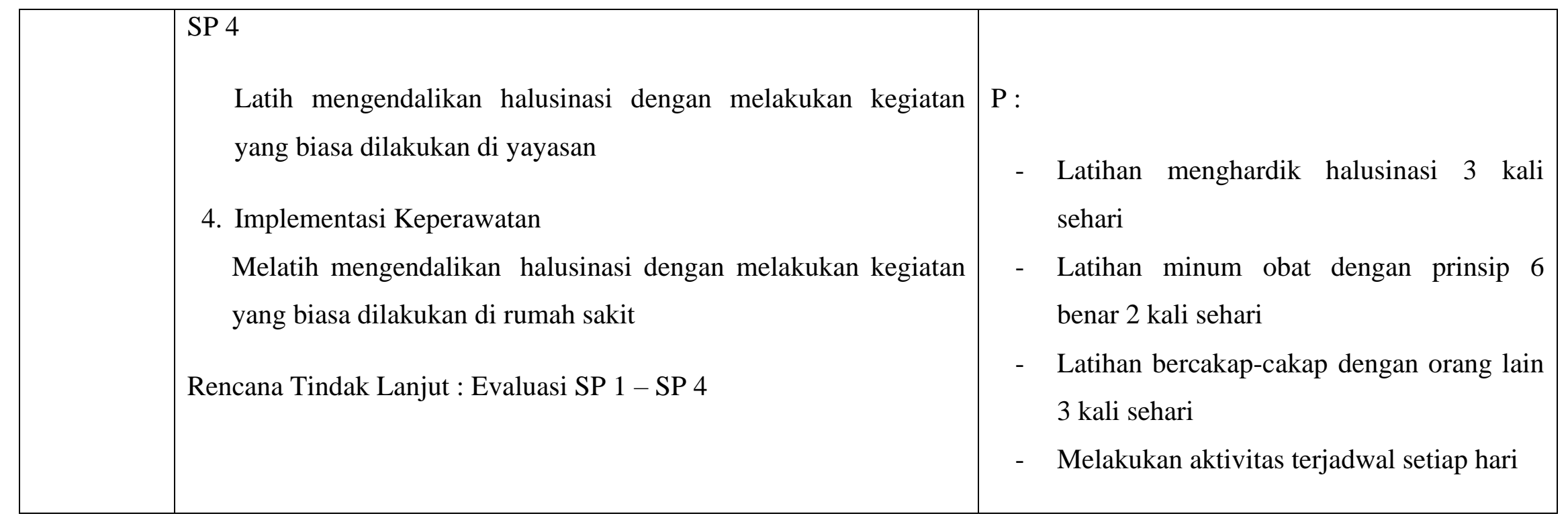




\section{BAB 4}

\section{PEMBAHASAN}

Setelah penulis melaksanakan asuhan keperawat kepada Ny. T dengan gangguan sensori persepsi: halusinasi pendengaran di Yayasan Pemenang Jiwa, maka penulis pada $\mathrm{BAB}$ ini akan membahasan kesenjangan antara teoritis dengan tinjauan kasus. Pembahasan dimulai melalui tahapan proses keperawatan yaitu pengkajian, diagnosa keparawatan, perencanaan, pelaksanaan dan evaluasi.

\subsection{Pengkajian}

Pada pembahasan ini diuraikan tentang hasil pelaksanaan tindakan keperawatan dengan pemberian terapi generalis pada klien halusinasi pendengaran. Pembahasan menyangkut analisis hasil penerapan terapi generalis terhadap masalah keperawatan halusinasi pendengaran. Tindakan keperawatan didasarkan pada pengkajian dan diagnosis keperawatan yang terdiri dari tindakan generalis yang dijabarkan sebagai berikut.

Tahap pengkajian pada klien halusinasi dilakukan interaksi perawat-klien melalui komunikasi terapeutik untuk mengumpulkan data dan informasi tentang status kesehatan klien. Pada tahap ini terjadi proses interaksi manusia, komunikasi, transaksi dengan peran yang ada pada perawat sebagaimana konsep tentang manusia yang bisa dipengaruhi dengan adanya proses interpersonal.

Selama pengkajian dilakukan pengumpulan data dari beberapa sumber, yaitu dari pasien dan tenaga kesehatan di ruangan. Penulis mendapat sedikit kesulitan dalam menyimpulkan data karena keluarga pasien jarang mengunjungi pasien di yayasan jiwa. Maka penulis melakukan pendekatan kepada pasien melalui komunikasi terapeutik yang lebih terbuka 
membantu pasien untuk memecahkan perasaannya dan juga melakukan observasi kepada pasien.

Adapun upaya tersebut yaitu:

a. Melakukan pendekatan dan membina hubungan saling percaya diri pada klien agar klien lebih terbuka dan lebih percaya dengan menggunakan perasaan.

b. Mengadakan pengkajian klien dengan wawancara

c. Mengadakan pengkajian dengan cara membaca status, melihat buku rawatan dan bertanya kepada pegawai ruangan sorik merapi.

Dalam pengkajian ini, penulis menemukan kesenjangan karena ditemukan. Pada kasus Ny. T, klien mendengar suara-suara yang menyuruh untuk melakukan bercakap cakap, gelisah, , mondar-mandir, tampak tegang, putus asa, sedih dan lain-lain. Gejala gejala yang muncul tersebut tidak semua mencakup dengan yang ada di teori klinis dari halusnasi (Keliat, dkk.2014). Akan tetapi terdapat faktor predisposisi maupun presipitasi yang menyebabkan kekambuhan penyakit yang dialami oleh Ny. T .

Tindakan keperawatan terapi generalis yang dilakukan pada Ny. T adalah strategi pertemuan pertama sampai pertemuan empat. Strategi pertemuan pertama meliputi mengidentifikasi isi, frekuensi, jenis, dan respon klien terhadap halusinasi serta melatih cara menghardik halusinasi. Strategi pertemuan kedua yang dilakukan pada Ny. T meliputi melatih cara mengendalikan dengan bercakap-cakap kepada orang lain. Strategi pertemuan yang ketiga adalah menyusun jadwal kegiatan bersama-sama dengan klien. Strategi pertemuan keempat adalah mengajarkan dan melatih Ny. T cara minum obat yang teratur. 


\subsection{Diagnosa Keperawatan}

Pada diagnosa keperawatan yang muncul sebanyak 3 diagnosa keperawatan yang meliputi:

1. Harga diri rendah

2. Isolasi social

3. Halusinasi

\subsection{Implementasi}

Pada tahap implementasi, penulis hanya mengatasi 2 masalah keperawatan yakni: diagnosa keperawatan halusinasi pendengaran dan harga diri rendah. Pada diagnosa keperawatan gangguan persepsi sensori halusinasi pendengaran dilakukan strategi pertemuan yaitu mengidentifikasi isi, frekuensi, waktu terjadi, perasaan, respon halusinasi. Kemudian strategi pertemuan yang dilakukan yaitu latihan mengontrol halusinasi dengan cara menghardik. Strategi pertemuan yang kedua yaitu anjurkan minum obat secara teratur, strategi pertemuan yang ke tiga yaitu latihan dengan cara bercakap-cakap pada saat aktivitas dan latihan strategi pertemuan ke empat yaitu melatih klien melakukan semua jadwal kegiatan.

Pada diagnosa keperawatan harga diri rendah strategi pertemuan yang dilakukan yaitu mengidentifikasi kemampuan dan aspek positif yang masih dimiliki klien. Strategi pertemuan yang kedua yaitu membantu klien menilai kemampuan yang dapat digunakan. Strategi pertemuan yang ketiga yaitu membantu klien memilih/menetapkan kemampuan yang akan dilatih. Strategi pertemuan yang keempat yaitu latih kemampuan yang dipilih klien.

Untuk melakukan implementsi pada keluarga, pada tahap-tahap diagnosa tidak dapat dilaksanakan karena penulis tidak pernah berjumpa dengan keluarga klien (keluarga tidak pernah berkunjung).

\subsection{Evaluasi Keperawatan}

Pada tinajauan teoritis evaluasi yang diharapkan adalah: Pasien mempercayai perawat sebagai terapis, pasien menyadari bahwa yang 
dialaminya tidak ada objeknya, dapat mengidentifikaasi halusinasi, dapat mengendalikan halusinasi melalui mengahrdik, latihan bercakap-cakap, melakukan aktivitas serta menggunakan obat secara teratur.

Pada tinjauan kasus evaluasi yang didapatkan adalah: Klien mampu mengontrol dan mengidentifikasi halusinasi, Klien mampu melakukan latihan bercakap-cakap dengan orang lain, Klien mampu melaksanakan jadwal yang telah dibuat bersama, Klien mampu memahami penggunaan obat yang benar: 5 benar. Selain itu, dapat dilihat dari setiap evalusi yang dilakukan pada asuhan keperawatan, dimana terjadi penurunan gejala yang dialami oleh Ny. T dari hari kehari selama proses interaksi. 


\section{BAB V}

\section{PENUTUP}

\subsection{Kesimpulan}

Berdasarkan uraian pada pembahasan di atas, maka penulis dapat disimpulkan bahwa:

1. Pengkajian dilakukan secara langsung pada klien dan juga dengan menjadikan status klien sebagai sumber informasi yang dapat mendukung data-data pengkajian. Selama proses pengkajian, perawat mengunakan komunikasi terapeutik serta membina hubungan saling percaya antara perawat-klien. Pada kasus Ny. T, diperoleh bahwa klien mengalami gejala-gejala halusinasi seperti mendengar suara-suara, gelisah, sulit tidur, tampak tegang, mondar-mandir,tidak dapat mempertahankan kontak mata, sedih, malu, putus asa, menarik diri, mudah marah dan lain-lain. Diagnosa keperawatan yang muncul pada kasus Ny. T , Halusinasi pendengaran, isolasi sosial, harga diri rendah. Tetapi pada pelaksanaannya, penulis fokus pada masalah utama yaitu halusinasi pendengaran.

2. Perencanaan dan implementasi keperawatan disesuaikan dengan strategi pertemuan pada pasien halusinasi pendengaran dan harga diri.

3. Evaluasi diperoleh bahwa terjadi peningkatan kemampuan klien dalam mengendalikan halusinasi yang dialami serta dampak pada penurunan gejala halusinasi pendengaran yang dialami.

\subsection{Saran}

1. Bagi Perawat

Diharapkan dapat menerapkan komunikasi terapeutik dalam pelaksanaan strategi pertemuan 1-3 pada klien dengan halusinasi sehingga dapat mempercepat proses pemulihan klien.

2. Bagi Institusi Pendidikan

Dapat meningkatkan bimbingan klinik kepada mahasiswa profesi ners sehingga mahasiswa semakin mampu dalam melakukan asuhan keperawatan pada pasien-pasien yang mengalami halusinasi pendengaran 


\section{Bagi Tempat}

Laporan ini diharapkan dapat menjadai acuan dan referensi dalam memberikan asuhan keperawatan pada klien dengan halusinasi pendengaran. 


\section{DAFTAR PUSTAKA}

Aji, W. M. H. (2019). Asuhan Keperawatan Orang Dengan Gangguan Jiwa Halusinasi Dengar Dalam Mengontrol Halusinasi. https://doi.org/10.31219/osf.io/n9dgs

Aldam, S. F. S., \& Wardani, I. Y. (2019). Efektifitas penerapan standar asuhan keperawatan jiwa generalis pada pasien skizofrenia dalam menurunkan gejala halusinasi. Jurnal Keperawatan Jiwa, 7(2), 165-172. https://doi.org/10.26714/jkj.7.2.2019.167-174

Aritonang, M. (2021). Efektifitas Terapi Aktivitas Kelompok Stimulasi Terhadap Kemampuan Mengontrol Halusinasi Pendengaran Pada Pasien Ruang Cempaka Di Rsj Prof. Dr. M. Ildrem Medan Tahun 2019. Jurkessutra: Jurnal Kesehatan Surya Nusantara,9(1). https://jurnal.suryanusantara.ac.id/index.php/jurkessutra/article/view/64

Dalami, E., Rochimah, N., Suryati, K. R., \& Lestari, W. (2009). Asuhan keperawatan klien dengan gangguan jiwa.

Erliyani, E. (2019) Gambaran Strategi Koping Pada Pasien Dengan Gangguan Persepsi Sensori Halusinasi: Pendengaran. Diploma (D3) thesis, University of Muhammadiyah Malang. http://eprints.umm.ac.id/id/eprint/49941

Keliat, B.A, \& Akemat. (2014). Model Praktik Keperawatan Profesional Jiwa. Jakarta. EGC.

Kemenkes RI. (2019). Riset Kesehatan Dasar; Riskesdas. Jakarta: Balitbang Kemenkes RI

Mubin, M. F., \& Livana, P. H. (2019). Hubungan Kepatuhan Minum Obat Dengan Kekambuhan Pasien Skizofrenia Paranoid. Jurnal Farmasetis, 8(1), 21-24.https://doi.org/10.32583/farmasetis.v8i1.493

Nyumirah, S. (2013). Peningkatan kemampuan interaksi sosial (kognitif, afektif dan perilaku) melalui penerapan terapi perilaku kognitif di rsj dr amino gondohutomo semarang. Jurnal keperawatan jiwa, 1(2). https://doi.org/10.26714/jkj.1.2.2013.\%25p

Oktiviani, D. P. (2020). Asuhan Keperawatan Jiwa Pada Tn. K dengan masalah Gangguan Persepsi Sensori: Halusinasi Pendengaran di Ruang Rokan Rumah Sakit Jiwa Tampan. Skripsi, Poltekkes Kemenkes Riau. http://repository.pkr.ac.id/id/eprint/498

Pardede, J. A., Keliat, B. A., \& Wardani, I. Y. (2013). Pengaruh Acceptance And Commitment Therapy Dan Pendidikan Kesehatan Kepatuhan Minum Obat Terhadap Gejala, Kemampuan Berkomitmen Pada Pengobatan Dan Kepatuhan Pasien Skizofrenia. FIK UI, Depok

Pardede, J. (2020). Family Knowledge about Hallucination Related to Drinking Medication Adherence on Schizophrenia Patient. Jurnal Penelitian Perawat Profesional, 2(4), 399-408. https://doi.org/10.37287/jppp.v2i4.183

Pardede, J. A., \& Siregar, R. A. (2016). Pendidikan Kesehatan Kepatuhan Minum Obat Terhadap Perubahan Gejala Halusinasi Pada Klienskizofrenia. Mental Health, 3(1).https://d1wqtxts1xzle7.cloudfront.net/63689754

Pardede, J. A., \& Hasibuan, E. K. (2019). Dukungan Caregiver Dengan Frekuensi Kekambuhan Pasien Skizofrenia. Idea Nursing Journal, 10(2). http://erepository.unsyiah.ac.id/INJ/article/view/17161 
Pima Astari, U. P. I. K. (2020). Studi Literatur: Asuhan Keperawatan Pada Penderita Skizofrenia Dengan Masalah Keperawatan Halusinasi Pendengaran (Doctoral dissertation, Universitas Muhammadiyah Ponorogo). http://eprints.umpo.ac.id/id/eprint/6192

Stuart, G. W. (2013). Buku Saku Keperawatan Jiwa. Edisi 5. Jakarta. EGC.

Stuart, G. W, Keliat, B. A, \& Pasaribu, J (2016). Prinsip dan Praktik Keperawatan Kesehatan Jiwa Stuart. Edisi Indonesia. Singapore: Elsevier

Widdayasih, \{2019\}, Penderita Gangguan Jiwa, http://wordpress.com

Yusuf, AH, Dkk. (2015). Buku Ajar Keperawatan Kesehatan Jiwa. Jakarta: Salemba Medika. 